\title{
The Abundance and Community Composition of Ammonia-Oxidizing Prokaryotes in Small-Reservoir Sediments in China's Huashan Watershed
}

\author{
Dayong Zhao ${ }^{1,2 *}$, Rui Huang, ${ }^{1,}$, Jin Zeng ${ }^{3}$, Juan Luo ${ }^{1,2}$, Feng Shen ${ }^{1,2}$, Cuiling Jiang², \\ Feng Huang ${ }^{2}$, Zhongbo Yu ${ }^{1,2}$, Qinglong L. Wu ${ }^{3}$ \\ ${ }^{1}$ State Key Laboratory of Hydrology-Water Resources and Hydraulic Engineering, Hohai University, \\ Nanjing 210098, China \\ ${ }^{2}$ College of Hydrology and Water Resources, Hohai University, Nanjing 210098, China \\ ${ }^{3}$ State Key Laboratory of Lake Science and the Environment, Nanjing Institute of Geography and Limnology, \\ Chinese Academy of Sciences, Nanjing 210008, China
}

Received: 30 March 2016

Accepted: 20 June 2016

\begin{abstract}
We investigated the effects of nutrient levels on the abundance and diversity of ammonia-oxidizing archaea (AOA) and ammonia-oxidizing bacteria (AOB), seven surface sediment samples from small reservoirs at different nutrient levels were collected from the eastern, central, and western parts of Huashan watershed in Chuzhou, Anhui Province to determine the abundance and community composition of AOA and AOB. The results showed that the abundance of bacterial amoA gene $\left(1.85 \times 10^{7}\right.$ to $2.86 \times 10^{8} \mathrm{~g} / \mathrm{dry}$ sediment) was higher than that of archaeal amo $A$ gene $\left(1.25 \times 10^{5}\right.$ to $1.23 \times 10^{6} \mathrm{~g} / \mathrm{dry}$ sediment $)$ in all sediment samples. The abundance of the archaeal amoA gene exhibited significant positive correlations with total nitrogen concentrations, whereas the abundance of bacterial amoA gene showed significantly negative correlation with $\mathrm{pH}$. Archaeal amoA gene sequences included Nitrososphaera and Nitrosopumilus clusters and the majority of Nitrosospira and Nitrosomonas oligotropha lineages.
\end{abstract}

Keywords: nitrogen cycling, ammonia-oxidizing prokaryotes, community composition, nutrient

\section{Introduction}

Nitrogen $(\mathrm{N})$ is an essential nutrient and limits biological productivity in most freshwater and marine ecosystems [1]. Nitrification, mediated by the microbial process, plays a central and critical role in global nitrogen cycling in both soils and sediments [2-3]. Bacteria were thought to be responsible for catalyzing the first and ratelimiting step of this process [3]. Recent studies have found that, in addition to ammonia-oxidizing bacteria (AOB), ammonia-oxidizing archaea (AOA) also could catalyze the process [4], and that AOA exists widely in various ecosystems [5-11].

*e-mail: dyzhao@hhu.edu.cn 
Previous studies have investigated the distribution of $\mathrm{AOA}$ and $\mathrm{AOB}$ in lake sediments [9-13], the rhizosphere of freshwater macrophytes [14], estuary sediments [15], mangrove sediments [16], and marine sediments [1, 17]. It has been found that AOA dominated in marine sediments $[1,17]$, indicated by its better adaptation to anaerobic, low $\mathrm{pH}$, and low ammonia habitats than AOB [18-19], whereas higher nutrients in the freshwater sediments promoted AOB dominance, such as river sediments [20], mangrove sediments $[16,21]$, and shore side wetlands [22]. Zhao et al. [13] found that the abundance of archaeal amo $A$ in lake sediment was higher than bacterial amoA, whereas Moiser and Francis [23] found that bacterial amo $A$ copy numbers were greater than archaeal amo $A$ in most of the estuary. This contradiction could be attributed to the different adaptations of the two ammonia-oxidizing groups to nutrients in different nutrient level sediments. It is important to figure out the relationships between the abundance and community composition of AOA and AOB and the sediment properties, including $\mathrm{pH}$ - and nitrogenassociated factors.

Previous studies have indicated that environmental factors such as $\mathrm{pH}$ [24], temperature [25], ammonium concentration [26], nitrogen fertilization [27-28], and organic carbon [28-29] could affect the abundance and community composition of AOA and AOB. $\mathrm{pH}$ significantly affected the AOA community in river sediments [20]. Elevated temperature increased AOA abundance, whereas it decreased AOB abundance [30]. Strong correlations were found between ammonium concentrations and the abundance of both AOA and AOB in mangrove [21] and freshwater sediments [9, 11]. Other nutrient elements such as available phosphorus could affect the community composition of AOA [9, 12]. Moreover, the concentration of organic carbon was found to significantly correlate with the community composition of AOA and AOB in the intertidal sediments of the Yangtze Estuary [15]. Moreover, the effects of nutrient levels on the abundance, diversity, and community compositions of AOA and AOB have been investigated. Wang et al. [31] investigated the effects of nitrogen fertilizer in rice soil and found that three major AOB groups (Nitrosomonas communis cluster, Nitrosospira clusters $3 \mathrm{a}$ and $3 \mathrm{~b}$ ) were clearly affected by $\mathrm{N}$ fertilizer, whereas the AOA community remained unchanged. Evidence revealed that AOB and AOA preferred different $\mathrm{N}$ levels for growth, with AOB growing significantly only at high ammonia nitrogen levels and AOA growing substantially at low ammonia nitrogen levels [32]. However, most of these results have been obtained in the soil ecosystem, which left gaps in the freshwater sediments.

Huashan watershed has been exploited by agriculture for years. The small reservoirs all over the watershed have been influenced by agricultural runoff. The reservoirs have been confirmed to be severely eutrophic with nitrogen input [33]. $\mathrm{pH}$ - and nitrogen-associated factors have been found to have significant effects on the community composition of AOA and AOB in soils [24, 27-28, 31]. Therefore, it is necessary to find out the differences of abundance and community composition of $\mathrm{AOA}$ and $\mathrm{AOB}$ at different nutrient levels in these reservoir sediments. In the present study, seven sediment samples from seven freshwater reservoirs with different nutrient levels were collected and subjected to chemical and molecular biological analysis to elucidate the effects of nutrient levels on the abundance and diversity of AOA and AOB.

\section{Materials and Methods}

\section{Sample Collection}

Our study was conducted in Huashan watershed in the eastern part of Chuzhou City in Anhui Province, China. Seven reservoirs were selected for sampling within the eastern, central, and western parts of the watershed on 27 November 2013, namely ZC (Zhuchong Reservoir: 32.2959N, 118.188898E), WY (Wangying Reservoir: (32.26846N, 118.156268E), SSK (Shishankou Dam: 32.28577N, 186.18611E), LQ (Longquan Reservoir: 32.24426N, 118.17009E), YF (Youfang Dam: 32.25742 N, 186.199439E), DSW (Dashanwa Reservoir: 32.22676N, 118.189137E), and HHQ (Honghuaqiao Reservoir: 32.27961N, 118.233967E). These seven small reservoirs are located at the branches of the main stream in this watershed. Restricted to agricultural nitrogen fertilizer, these sampling reservoirs were under the impact of the nitrogenous process. Three sampling sites were randomly selected as replicates at each target reservoir. Surface sediment columns were collected at each site with the columnar sediment sampler (11 cm diameter; HYDROBIOS, Germany). All samples were transferred to sterile tubes immediately after sampling, refrigerated with ice, and then transported to a laboratory for further analysis. Surface sections $(0-1 \mathrm{~cm})$ of each site were separated. Water samples were collected at $0.5 \mathrm{~m}$ depth in each reservoir and the concentrations of $\mathrm{COD}_{\mathrm{Mn}}$ were measured using titration. The air temperature was $7^{\circ} \mathrm{C}$ on sampling day.

\section{Physicochemical Analysis of Sediment Samples}

All seven sediment samples were dried with a freeze dryer (ALPHA1-2, CHRIST, Germany). Total nitrogen (TN) was measured using an elemental analyzer (EA3000, Euro Vector, Italy). Sediment ammonia and nitrate concentrations were extracted with $2 \mathrm{M} \mathrm{KCl}$ and measured by a continuous flow analyzer (San++, SKALER, Netherlands). Sediment samples were measured for $\mathrm{pH}$ after being treated with $2 \mathrm{M} \mathrm{KCl}$. The physicochemical analysis included three replicates for each sample.

\section{DNA Extraction}

DNA was extracted from $0.25 \mathrm{~g}$ sediment sample using a PowerSoil DNA Isolation Kit (MoBio Laboratory, Solana Beach, CA). DNA was extracted from the three 
replicates and combined. The extracted DNA was checked on $0.8 \%$ agarose gel and the concentration of the extracted DNA was determined using a BioPhotometer (Eppendorf, Hamburg, Germany).

\section{Real-Time Quantitative PCR}

Real-time quantitative PCR was performed using SYBR Green I on an IQ5 Thermocycler (RG65HD, Corbett, Australia). The primers for archaeal amoA PCR amplification were Arch-amoAF/Arch-amoAR [1], and the primers for bacterial amoA PCR amplification were amoA-1F/amoA-2R [34]. The standard curve was constructed by 10 -fold serial dilutions of plasmid DNA of a known concentration covering $3.40 \times 10^{2}$ to $3.40 \times 10^{8}$ of archaeal amo $A$ copies per $\mu$, and $1.59 \times 10^{2}$ to $1.59 \times 10^{8}$ of bacterial amoA copies per $\mu \mathrm{l}$.

The volumes of reaction mixtures for archaeal and bacterial amoA PCR amplification were $20 \mu \mathrm{l}$, including 5 ng of DNA template, $1 \times$ SYBR Premix Ex Taq buffer (Takara, Japan), and $0.2 \mu \mathrm{M}$ each of archaeal or bacterial amo $A$ primers. For the thermal cycles, the protocol for archaeal amo $A$ PCR amplification was as follows: $3 \mathrm{~min}$ at $95^{\circ} \mathrm{C}, 45$ cycles of $30 \mathrm{~s}$ at $95^{\circ} \mathrm{C}, 1 \mathrm{~min}$ at $53^{\circ} \mathrm{C}, 20 \mathrm{~s}$ at $72^{\circ} \mathrm{C}$, and $7 \mathrm{~min}$ at $72^{\circ} \mathrm{C}$. The protocol for bacterial amo $A$ PCR amplification was as follows: $3 \mathrm{~min}$ at $95^{\circ} \mathrm{C}$, 45 cycles of $30 \mathrm{~s}$ at $95^{\circ} \mathrm{C}, 1 \mathrm{~min}$ at $55^{\circ} \mathrm{C}, 20 \mathrm{~s}$ at $72^{\circ} \mathrm{C}$, and $7 \mathrm{~min}$ at $72^{\circ} \mathrm{C}$.

Melting curve and $2 \%$ agarose gel electrophoresis were employed to check the specificity of the PCR products. Data analysis was carried out with the Rotor-Gene 6000 software package. The PCR amplification efficiencies were 0.97-1.02 for archaeal amoA and 0.95-0.98 for bacterial $a m o A$. The obtained data were calculated with the mass of the sediment samples to determine the abundance of archaeal and bacterial amo $A$ copies per gram sediment (dry weight).

\section{Clone Library and Phylogenetic Analysis}

Clone libraries were constructed with the DNA extracted from the seven sediment samples. PCR reactions were carried out with Ex Taq DNA polymerase (Takara, Otsu, Japan) in all amoA PCR amplifications. Triplicate PCR products were pooled, gel-purified using the Axygen PCR cleanup purification kit, and cloned by the pGEM-T vector (Promega, Madison, WI, USA). The resulting ligation products were used to transform to Escherichia coli-competent cells (DH5 $\alpha$, Takara, Japan). Picked transformants were grown overnight on LB agar plates containing $100 \mu \mathrm{g} / \mathrm{mL}$ ampicillin, $40 \mu \mathrm{g} / \mathrm{mL} \mathrm{X-Gal,} \mathrm{and} 24$ $\mu \mathrm{g} / \mathrm{mL}$ IPTG. Clones were checked by PCR amplification using vector primers (T7 and SP6) and conveyed to Shanghai MajorBio Biotechnology Co., Ltd. for DNA sequencing.

The sequences acquired in accordance with the above procedure were translated into conceptual protein sequences. All amoA sequences were compared with GenBank database sequences using BLAST. Operational taxonomic units (OTUs) were defined as sequence groups in which sequences differed by $\leq 5 \%$ nucleotide differences. Amino acid sequence alignments were generated using ClustalX [35]. Indices of diversity and nonparametric richness estimations were performed using DOTUR software [36]. The estimated coverage of the constructed amo $A$ gene sequences was calculated as $C=\left[1-\left(n_{1} / N\right)\right]$ $\times 100 \%$, where $n_{1}$ is the number of singletons sequences and $N$ is the total number of sequences. Neighbor-joining phylogenetic trees (based on Jukes-Cantor distances) were constructed based on alignments of amino acid sequences using MEGA4.0 [37].

\section{Statistical Analysis}

Significant differences of sediment properties and the abundance of archaeal or bacterial amo $A$ were assessed by one-way ANOVA and post hoc comparisons with the SPSS 13.0 package (SPSS, Chicago, IL). Correlation analysis (two-tailed Pearson correlation coefficients) between amoA abundance and environmental factors were also performed. P-values $<0.05$ were considered statistically significant.

\section{Nucleotide Sequence Accession Numbers}

The amo $A$ sequences obtained in this study have been deposited in the GenBank database under accession numbers KJ583248-KJ583307, KJ583338-KJ583457, and KJ583488-KJ583517 for archaeal amoA sequences, and KJ583548-KJ583643, KJ583691-KJ583875, and KJ583924-KJ583973 for bacterial amoA sequences.

\section{Results}

\section{Physicochemical Properties of Sediment Samples}

The $\mathrm{pH}$ of sediments collected in the present study was generally neutral (Table 1). The lower $\mathrm{pH}$ was found in the sediments of Zhuchong $(\mathrm{pH}=6.66)$ and Longquan ( $\mathrm{pH}=6.98)$ reservoirs. The $\mathrm{pH}$ values of sediment samples in Wangying and Honghuaqiao reservoirs were highest (7.36 and 7.34). The concentration of $\mathrm{COD}_{\mathrm{Mn}}$ in Wangying Reservoir was remarkably lower $(2.42 \mathrm{mg} / \mathrm{L})$ than those of other samples, whereas higher concentrations of $\mathrm{COD}_{\mathrm{Mn}}$ were found in Zhuchong (7.88 $\mathrm{mg} / \mathrm{L})$, Longquan (7.32 $\mathrm{mg} / \mathrm{L})$ and Dashanwa $(7.48 \mathrm{mg} / \mathrm{L})$ reservoirs. The nitrate concentration of the sediment sample collected from Shishankou Dam $(0.86 \mathrm{mg} / \mathrm{kg})$ was significantly higher than that of the others, whereas the nitrate concentrations in sediment samples of Youfang Dam (0.46 mg/kg), Dashanwa Reservoir (0.36 mg/kg), and Wangying Reservoir $(0.25 \mathrm{mg} / \mathrm{kg})$ were significantly lower. The highest ammonia nitrogen concentration was found in the sediment sample of Longquan Reservoir $(47.87 \mathrm{mg} / \mathrm{kg})$. Lower concentrations of ammonia were found at Dashanwa $(15.31 \mathrm{mg} / \mathrm{kg})$ and Honghuaqiao 
Table 1. The physicochemical parameters of different sediment samples collected from Huashan Watershed. Data are presented as means \pm standard deviation $(\mathrm{n}=3)$. Different letters indicate significant differences between samples.

\begin{tabular}{|c|c|c|c|c|c|}
\hline Sample sites & $\mathrm{pH}$ & $\mathrm{COD}_{\mathrm{Mn}}(\mathrm{mg} / \mathrm{L})$ & $\begin{array}{c}\mathrm{NO}_{3}^{-}-\mathrm{N} \\
(\mathrm{mg} / \mathrm{kg})\end{array}$ & $\begin{array}{c}\mathrm{NH}_{4}^{+}-\mathrm{N} \\
(\mathrm{mg} / \mathrm{kg})\end{array}$ & $\begin{array}{c}\mathrm{TN} \\
(\mathrm{mg} / \mathrm{kg})\end{array}$ \\
\hline ZC & 6.66 & 7.88 & $0.65 \pm 0.11^{\mathrm{c}}$ & $19.65 \pm 2.15^{\mathrm{a}}$ & $590.73 \pm 27.62^{\mathrm{a}}$ \\
\hline WY & 7.36 & 2.42 & $0.25 \pm 0.02^{\mathrm{a}}$ & $39.26 \pm 3.39^{\mathrm{c}}$ & $1315.68 \pm 36.54^{\mathrm{d}}$ \\
\hline SSK & 7.26 & 5.08 & $0.86 \pm 0.07^{\mathrm{d}}$ & $31.27 \pm 3.89^{\mathrm{b}}$ & $922.59 \pm 37.81^{\mathrm{b}}$ \\
\hline LQ & 6.98 & 7.32 & $0.69 \pm 0.04^{\mathrm{c}}$ & $47.87 \pm 5.95^{\mathrm{d}}$ & $1097.21 \pm 83.99^{\mathrm{c}}$ \\
\hline YF & 7.01 & 5.50 & $0.46 \pm 0.05^{\mathrm{b}}$ & $28.58 \pm 3.85^{\mathrm{b}}$ & $1053.79 \pm 124.38^{\mathrm{c}}$ \\
\hline DSW & 7.22 & 7.48 & $0.36 \pm 0.04^{\mathrm{ab}}$ & $15.31 \pm 1.91^{\mathrm{a}}$ & $880.22 \pm 63.68^{\mathrm{b}}$ \\
\hline HHQ & 7.34 & 5.60 & $0.76 \pm 0.10^{\mathrm{cd}}$ & $16.02 \pm 1.37^{\mathrm{a}}$ & $580.12 \pm 21.51^{\mathrm{a}}$ \\
\hline
\end{tabular}

$\mathrm{COD}_{\mathrm{Mn}}$ : chemical oxygen demand; $\mathrm{NO}_{3}^{-}-\mathrm{N}$ : nitrate nitrogen, $\mathrm{NH}_{4}^{+}-\mathrm{N}$ : ammonia nitrogen, $\mathrm{TN}$ : total nitrogen, ZC: Zhuchong Reservoir, WY: Wangying Reservoir, SSK: Shishankou Dam, LQ: Longquan Reservoir, YF: Youfang Dam, DSW: Dashanwa Reservoir, HHQ: Honghuaqiao Reservoir.

$(16.02 \mathrm{mg} / \mathrm{kg})$ reservoirs. Significant differences were observed in the TN concentrations from all the sediment samples. The sediment sample from Wangying Reservoir contained high levels of TN (1315.68 mg/kg), whereas lower levels of TN appeared in Zhuchong $(590.73 \mathrm{mg} / \mathrm{kg})$ and Honghuaqiao $(580.12 \mathrm{mg} / \mathrm{kg}$ ) reservoirs.

\section{Abundance of Archaeal} and Bacterial amo $A$ Genes

The abundance of archaeal amo $A$ ranged from $1.25 \times 10^{5}$ copies per gram of dry sediment to $1.23 \times 10^{6}$ copies per gram of dry sediment, whereas the abundance of the bacterial amoA ranged from $1.42 \times 10^{7}$ copies per gram of dry sediment to $2.86 \times 10^{8}$ copies per gram of

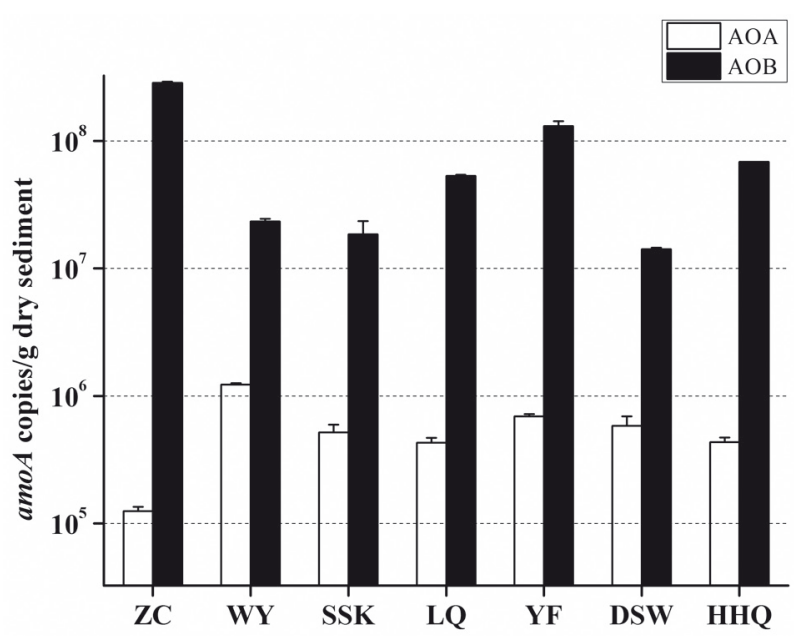

Fig. 1 The copy numbers of the archaeal (white columns) and bacterial (black columns) amo $A$ genes in different sediment samples. Data are presented as means \pm standard deviation $(\mathrm{n}=3)$. ZC: Zhuchong Reservoir; WY: Wangying Reservoir; SSK: Shishankou Dam; LQ: Longquan Reservoir; YF: Youfang Dam; DSW: Dashanwa Reservoir; HHQ: Honghuaqiao Reservoir. dry sediment (Fig. 1). Bacterial amo $A$ abundances were higher than those of the archaeal amoA abundance in all sediment samples. The highest archaeal amoA abundance was found in the sample from Wangying Reservoir and the lowest from Zhuchong Reservoir. No significant changes in archaeal amoA abundance were observed among all the other five sediment samples with all values between $10^{5}$ and $10^{6}$ copies per gram of dry sediment. In contrast, samples collected from Zhuchong Reservoir were found to be the highest bacterial amo $A$ abundance of $2.86 \times 10^{8}$ copies per gram of dry sediment, followed by the sediment samples from Youfang Dam $\left(1.31 \times 10^{8}\right.$ copies per gram of dry sediment) and Honghuaqiao Reservoir $\left(6.85 \times 10^{7}\right.$ copies per gram of dry sediment), whereas the Dashanwa Dam sediment sample was the lowest - even lower than that of Zhuchong Reservoir by nearly one order of magnitude. Other samples demonstrated similar abundance in bacterial amo $A$ with all values slightly above $10^{7}$ copies per gram of dry sediment.

\section{Diversity Analysis of Archaeal and Bacterial amoA Genes}

In total, 210 archaeal amo $A$ sequences and 331 bacterial amo $A$ sequences were recognized, respectively (Table 2). Operational taxonomic units (OTUs) were calculated using the DOTUR software package [37]. Consequently, 68 OTUs were generated for the archaeal amoA clone library, whereas the number of OTUs in the bacterial amoA clone library was 52 in total. Among individual clone libraries, the number of OTUs ranged from 5 to 14 for both archaeal amo $A$ and bacterial $a m o A$. For archaeal $a m o A$, Longquan Reservoir sediment contained 14 OTUs, which was nearly three times as high as Dashanwa Reservoir. For bacterial amoA, Longquan Reservoir and Youfang Dam sediment samples both contained 14 OTUs, whereas the lowest number was observed in the sediment of Zhuchong Reservoir (5 OTUs). The clone library coverage varied from $76.6 \%$ (Longquan Reservoir) to $96.7 \%$ (Dashanwa Reservoir and Honghuaqiao Reservoir) for archaeal 
Table 2. Diversity of the archaeal and bacterial amoA gene sequences from different sediment samples collected from Huashan Watershed.

\begin{tabular}{|c|c|c|c|c|c|}
\hline Samples & $\begin{array}{l}\text { Number } \\
\text { of clones }\end{array}$ & $\begin{array}{l}\text { Number } \\
\text { of OTUs }\end{array}$ & $\mathrm{C} \%$ & $S_{\text {chaol }}$ & $H^{\prime}$ \\
\hline \multicolumn{6}{|c|}{$\mathrm{AOA}$} \\
\hline $\mathrm{ZC}$ & 30 & 9 & 80 & 16.5 & 1.55 \\
\hline WY & 30 & 7 & 90 & 8.5 & 1.52 \\
\hline SSK & 30 & 11 & 80 & 14.8 & 1.80 \\
\hline LQ & 30 & 14 & 76.7 & 21 & 2.42 \\
\hline YF & 30 & 12 & 80 & 17 & 2.18 \\
\hline DSW & 30 & 10 & 96.7 & 10 & 2.15 \\
\hline HHQ & 30 & 5 & 96.7 & 5 & 1.38 \\
\hline \multicolumn{6}{|c|}{$\mathrm{AOB}$} \\
\hline $\mathrm{ZC}$ & 50 & 5 & 96 & 5.5 & 0.84 \\
\hline WY & 46 & 11 & 89.1 & 16 & 1.93 \\
\hline SSK & 47 & 9 & 93.6 & 10 & 1.68 \\
\hline LQ & 43 & 14 & 83.7 & 18.7 & 1.73 \\
\hline YF & 50 & 14 & 84 & 42 & 2.18 \\
\hline DSW & 45 & 8 & 88.9 & 13 & 1.21 \\
\hline HHQ & 50 & 11 & 90 & 16 & 1.90 \\
\hline
\end{tabular}

$\mathrm{C} \%$ : coverage of each clone library, $S_{\text {chaol }}$ : the Chao 1 index, $H^{\prime}$ : the Shannon-Wiener index, ZC: Zhuchong Reservoir, WY: Wangying Reservoir, SSK: Shishankou Dam, LQ: Longquan Reservoir, YF: Youfang Dam, DSW: Dashanwa Reservoir, HHQ: Honghuaqiao Reservoir.

$a m o A$, and from $83.7 \%$ (Longquan Reservoir) to $96 \%$ (Zhuchong Reservoir) for bacterial amoA. Diversity indices of Shannon-Wiener $\left(H^{\prime}\right)$ and $S_{\text {Chaol }}$ demonstrated that the Longquan Reservoir sediment sample (2.42 and 21 , respectively) had the highest diversity for archaeal amo $A$ and the Youfang Dam sediment sample (2.18 and 42 , respectively) maintained the highest diversity for bacterial amoA, whereas the Honghuaqiao Reservoir sediment sample (1.38 and 5, respectively) had the lowest diversity for archaeal amoA and the Zhuchong Reservoir sediment sample ( 0.84 and 5.5 , respectively) had the lowest diversity for bacterial amoA.

\section{Relationships between Environmental Factors and Abundance, Diversity of Archaeal and Bacterial amo $A$ Genes}

Pearson's correlation coefficients were calculated to investigate the relationships between environmental factors and the abundance and diversity of archaeal and bacterial amoAs (Table S1). The abundance of the bacterial amoA gene was negatively correlated to $\mathrm{pH}$ $(P<0.05)$, whereas there was no significant correlation found between archaeal amo $A$ abundance and $\mathrm{pH}$ (Table $\mathrm{S} 1)$. TN concentrations exhibited positive relationships with the abundance of the archaeal amo $A$ gene $(P<0.05)$. However, TN concentrations showed no significant correlations with the abundance of the bacterial amo $A$ gene. The concentration of $\mathrm{COD}_{\mathrm{Mn}}$ was found to significantly negatively correlate with the abundance of the archaeal amo $A$ gene $(P<0.05)$. No other environmental factors showed significant correlations with the numbers of both archaeal and bacterial amoA OTUs.

\section{Phylogenetic Analysis of Archaeal and Bacterial amo $A$ Genes}

In the present study, all the obtained archaeal amo $A$ sequences are affiliated with two major clusters: $69.05 \%$ of all the sequences fell into the Nitrososphaera cluster, and the others fell into Nitrosopumilus cluster (Fig. S1a). Archaeal amoA sequences isolated from Zhuchong Reservoir contained only the Nitrososphaera cluster, suggesting that this sample was low in the diversity in the community composition of archaeal amoA sequences, whereas all of the other samples contained both two clusters in archaeal amo $A$ sequences with different percentages (Fig. 2a). The Nitrososphaera cluster was predominant with a high percentage $\geq 90 \%$ in all

Table S1. Pearson correlation coefficients of environmental variables and abundance as well as diversity of AOA and AOB communities.

\begin{tabular}{|c|c|c|c|c|c|c|c|c|c|}
\hline \multirow{2}{*}{$\begin{array}{c}\text { Environmental } \\
\text { variables }\end{array}$} & \multicolumn{9}{|c|}{ Pearson correlation coefficients } \\
\cline { 2 - 11 } & $\begin{array}{c}\text { amoA } \\
\text { abundance }\end{array}$ & $\begin{array}{c}\text { OTU } \\
\text { numbers }\end{array}$ & $\mathrm{S}_{\text {chaol }}$ & $H^{\prime}$ & $\begin{array}{c}\text { AmoA } \\
\text { abundance }\end{array}$ & $\begin{array}{c}\text { OTU } \\
\text { numbers }\end{array}$ & $\mathrm{S}_{\text {chaol }}$ & $H^{\prime}$ \\
\hline $\mathrm{pH}$ & 0.653 & -0.437 & -0.718 & -0.230 & $-0.870^{*}$ & 0.290 & 0.026 & 0.554 \\
\hline $\mathrm{COD}_{\mathrm{Mn}}$ & $-0.863^{*}$ & 0.406 & 0.449 & 0.419 & 0.449 & -0.323 & -0.204 & -0.663 \\
\hline $\mathrm{NO}_{3}^{-}-\mathrm{N}$ & -0.707 & 0.121 & 0.246 & -0.100 & 0.148 & -0.085 & -0.289 & -0.087 \\
\hline $\mathrm{NH}_{4}^{+}-\mathrm{N}$ & 0.388 & 0.531 & 0.534 & 0.408 & -0.292 & 0.602 & 0.199 & 0.427 \\
\hline $\mathrm{TN}$ & $0.815^{*}$ & 0.372 & 0.207 & 0.409 & -0.521 & 0.578 & 0.398 & 0.532 \\
\hline
\end{tabular}

$* P<0.05 . S_{\text {chaol }}$ : the Chao 1 index, $H^{\prime}$ : the Shannon-Wiener index, $\mathrm{COD}_{\mathrm{Mn}}$ : chemical oxygen demand, $\mathrm{NO}_{3}^{-}-\mathrm{N}$ : nitrate nitrogen, $\mathrm{NH}_{4}^{+}-\mathrm{N}$ : ammonia nitrogen, $\mathrm{TN}$ : total nitrogen. 

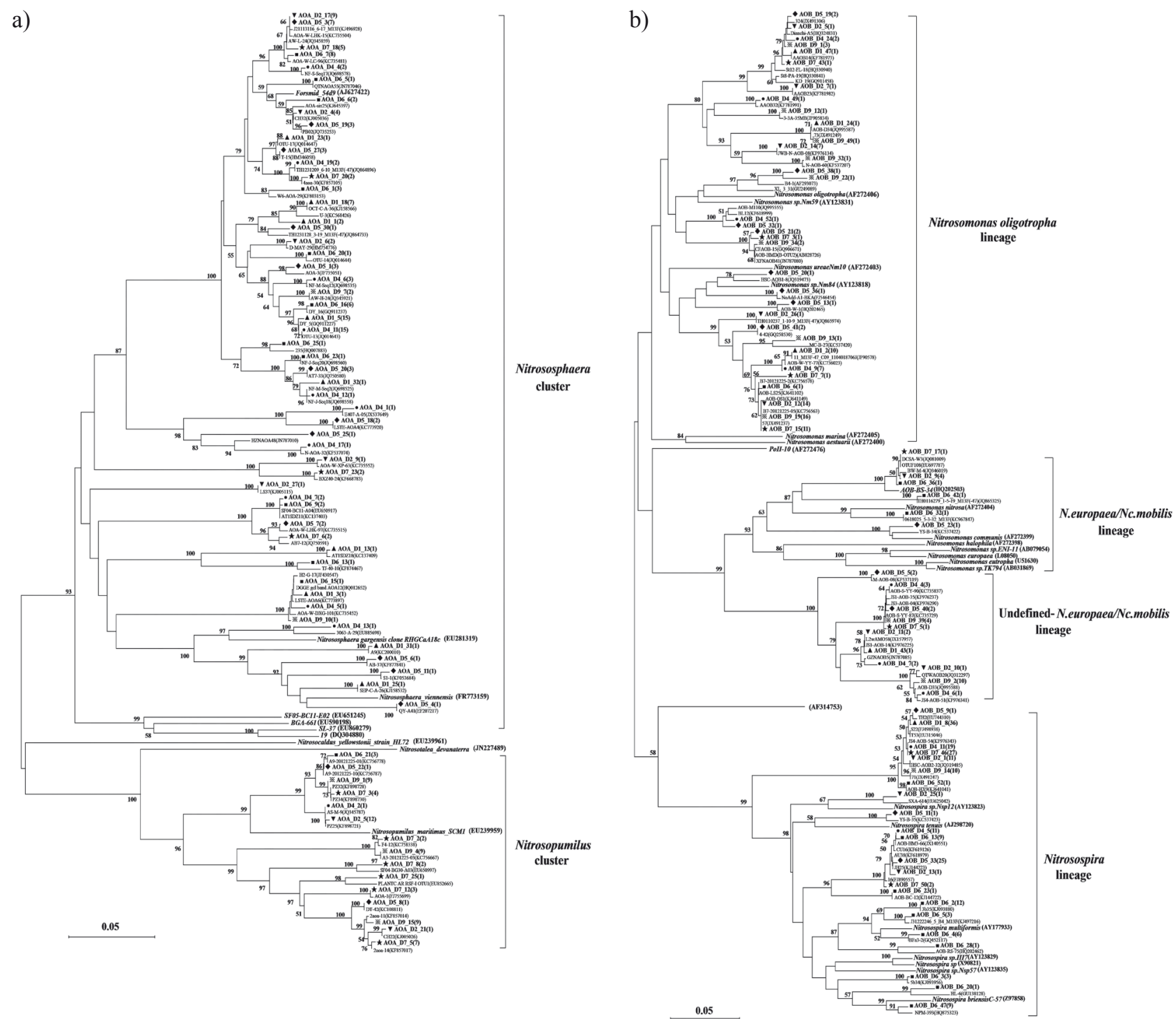

Fig. S1 Phylogenetic trees of archaeal a) and bacterial b) amoA gene sequences obtained in this study ( $\mathbf{\Delta}$ : Zhuchong Reservoir; $\boldsymbol{\nabla}$

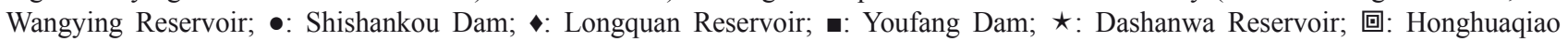
Reservoir). Only the representative sequences from each OTU were presented and the numbers in parentheses indicated the number of sequences affiliated to the same OTU. Only bootstrap values greater than $50 \%$ are shown near nodes.

archaeal amoA sequences of Shishankou Dam (97\%), Longquan Reservoir (93\%), and Youfang Dam (90\%) (Fig. 2a). The sediment sample from Wangying Reservoir contained Nitrososphaera and Nitrosopumilus clusters with similar percentages (57\% and $43 \%$, respectively). The Nitrosopumilus cluster was predominant in the sediment samples collected from Dashanwa $(63 \%)$ and Honghuaqiao (90\%) reservoirs (Fig. 2a).

Bacterial amoA sequences obtained in this study were divided into Nitrosomonas oligotropha, Nitrosospira, N.europaea/Nc.mobilis, and undefined- N.europaeal Nc.mobilis lineages (Fig. S1b). All the sediment samples contained Nitrosomonas oligotropha and Nitrosospira lineages with distinct proportions. The Nitrosomonasoligotropha lineage was predominant in sediments collected from Wangying $(52 \%)$ and Honghuaqiao $(54 \%)$ reservoirs, whereas other samples were all predominant in the Nitrosospira lineage (Fig. 2b). The highest percentage of Nitrosospira lineage appeared in sediment from Youfang Dam (92\%), followed by sediments from Zhuchong Reservoir (73\%), Dashanwa Reservoir (65\%), Shishankou Dam (64\%), and Longquan Reservoir (63\%) (Fig. 2b). Except for Nitrosomonas oligotropha and Nitrosospira lineages, the undefined N.europaea/Nc.mobilis lineage was the only cluster found in the sediments of Zhuchong Reservoir, Shishankou Dam, and Honghuaqiao Reservoir $(2 \%, 13 \%$, and $28 \%$, respectively). The N.europaea/Nc.mobilis lineage was the only cluster collected from Youfang Dam with a relative percentage of $6 \%$ (except for Nitrosomonas oligotropha and Nitrosospira lineages). Wangying, Longquan, and Dashanwa sediment samples contained all four lineages, suggesting that they maintained high bacterial amoA sequence diversity (Fig. 2b). 

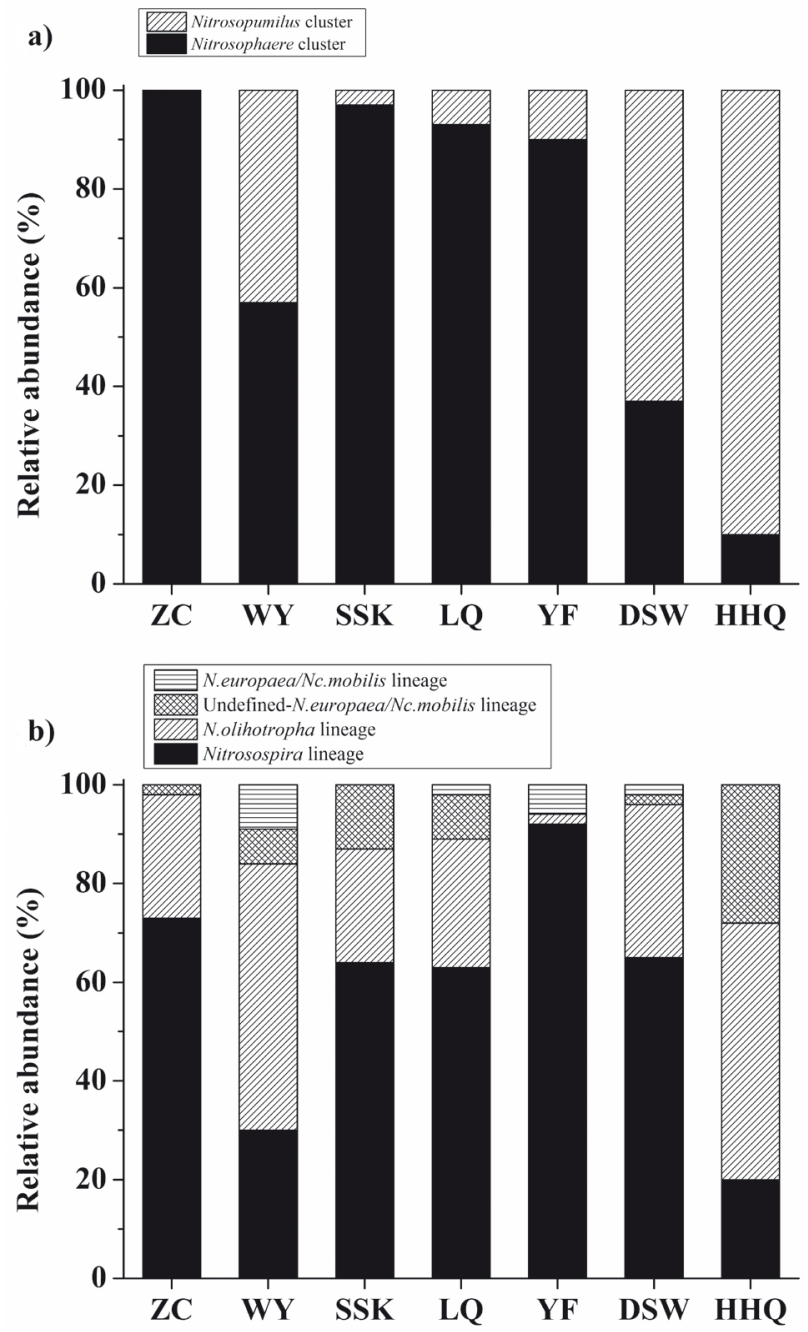

Fig. 2 Relative proportions of archaeal a) and bacterial b) amoA gene representing different groups from different sediment samples. ZC: Zhuchong Reservoir; WY: Wangying Reservoir; SSK: Shishankou Dam; LQ: Longquan Reservoir; YF: Youfang Dam; DSW: Dashanwa Reservoir; HHQ: Honghuaqiao Reservoir.

\section{Discussion}

Ammonia oxidation is the first and rate-limiting step of nitrification and plays an important role in the nitrogen cycling of various ecosystems. A recent study has found that the trophic status can affect the abundance and diversity of AOA and AOB [38]. In this study, seven sediment samples with distinct trophic status were collected to elucidate the relationships between nutrient levels and the abundance and diversity of AOA and AOB.

In the present study, bacterial amoA abundance was higher than archaeal amoA abundance in all sediment samples. Previous research showed that the abundance of AOA and AOB changed in various sediments [9, 12-13, 39]. Limpiyakorn et al. [40] found that the abundance of AOB was more than four orders of magnitude greater than AOA, which was similar to the present study. In contrary, Zhao et al. [13] found that abundance of AOA was higher than AOB in unvegetated sediment of Lake Taihu. Another study demonstrated that AOA far outnumbered AOB in sediments of Lake Taihu [39]. These discrepancies may be caused by different sediment environments. A previous report had shown that the sediment type and living substrates were suggested to affect abundances of ammonia oxidizers [41].

In the present study, $\mathrm{pH}$ was only found to negatively correlate with AOB abundance. Previous studies have demonstrated that $\mathrm{pH}$ is the key factor determining the abundance and community composition of AOA and AOB. Nicol et al. [24] found that AOA abundance decreased with elevated soil $\mathrm{pH}$, whereas AOB abundance increased with elevated $\mathrm{pH}$. Another study showed that soil $\mathrm{pH}$ was significantly positively correlated with the abundance of AOB [27], which was inconsistent with the present study. These differences may be attributed to the narrower $\mathrm{pH}$ range (6.66-7.36) in the present study compared to the previous studies ( $\mathrm{pH}$ ranging 4.5-7.5).

The results of Pearson correlation analysis demonstrated that TN was positively correlated with AOA abundance. However, ammonia concentration was found to be of no significant correlation with AOA abundance. AOA was known for its preference to live in low ammonia nitrogen environments [42]. It was not found in the present study. Samples of LQ and DSW were found to be the highest and lowest ammonia concentrations, respectively, while the abundances of AOA in these two samples were generally moderate.

AOA sequences obtained from different sediment samples contained two major clusters, Nitrososphaera and Nitrosopumilus. The results of correlation analysis indicated that the relative percentage of Nitrosopumilus was positively related to $\mathrm{pH}$, whereas nutrient levels showed no obvious correlation with any clusters of AOA. The result was in accordance with previous research that AOA community composition remained unchanged with three levels of $\mathrm{N}$ (urea) fertilizer in rice soil [31]. Limited information was available about the effect of trophic status on the community composition of AOA. Thus, more studies need to be undertaken to elucidate the mechanism of ammonia oxidation.

AOB sequences obtained in this study were divided into four lineages: Nitrosomonas oligotropha, Nitrosospira, N.europaea/Nc.mobilis, and undefinedN.europaea/Nc.mobilis lineages. The relative percentages of the N.europaea/Nc.mobilis lineage was found to be positively correlated with $\mathrm{TN}(\mathrm{R}=0.824, P<0.05)$ and negatively correlated with nitrate nitrogen $(\mathrm{R}=-0.817$, $P<0.05$ ). In the sediments samples of $\mathrm{ZC}, \mathrm{DSW}$, and HHQ with low ammonium nitrogen concentrations, the N.europaea/Nc.mobilis lineage was found to barely exist, which was consistent with the study of Sui et al. [43], who found that the diversity of the AOB community declined with the decreased ammonium nitrogen concentrations and N.europaea gradually disappeared. Wang et al. [31] conducted a microcosm experiment to determine the effects of nitrogen fertilizer on the composition of $\mathrm{AOB}$ and AOA communities, and results showed that Nitrosospira decreased with the increasing application of $\mathrm{N}$ fertilizer 
- in contrast to our results. In the sediment samples of SSK, LQ, and YF with higher nitrogen input, the Nitrosospira cluster demonstrated correspondingly higher abundance. Another analysis of bacterial amoA sequences revealed that the N.europaea cluster is commonly found with high ammonium levels and the $N$. oligotropha is the dominant cluster with low ammonium levels [40]. The findings in this study were not remarkable.

\section{Conclusion}

In the present study, seven surface sediment samples from small reservoirs were collected and investigated for the abundance and community composition of AOA and AOB. The abundance of the bacterial amoA gene was higher than that of the archaeal amo $A$ gene in all samples. The highest diversity of archaeal amoA gene was found in the LQ reservoir and the highest diversity of bacterial amoA gene was found in the YF reservoir. Significant positive correlation was found between TN and the abundance of archaeal amoA gene, and significant negative correlation was found between $\mathrm{pH}$ and the abundance of the bacterial amoA gene. Nitrososphaera and Nitrosopumilus clusters were the main clusters of archaeal amo $A$ sequences. Bacterial amo $A$ sequences mainly consisted of Nitrosospira and Nitrosomonas oligotropha lineages. The distinctive nutrient levels in the seven reservoirs remarkably affected the abundance and community composition of AOA and AOB. Further studies need to be undertaken to elucidate the mechanism underlying how trophic status changes the abundance and community composition of AOA and AOB.

\section{Abbreviations}

$\begin{array}{ll}\text { Abbreviation } & \text { Full name } \\ \text { AOA } & \text { ammonia-oxidizing archaea } \\ \text { AOB } & \text { ammonia-oxidizing bacteria } \\ \text { amoA } & \text { ammonia monooxygenase } \alpha \text {-subunit } \\ \text { ZC } & \text { Zhuchong Reservoir } \\ \text { WY } & \text { Wangying Reservoir } \\ \text { SSK } & \text { Shishankou Dam } \\ \text { LQ } & \text { Longquan Reservoir } \\ \text { YF } & \text { Youfang Dam } \\ \text { DSW }^{-} & \text {Dashanwa Reservoir } \\ \text { HHQ }^{\text {N }} & \text { Honghuaqiao Reservoir } \\ \mathbf{N}^{\text {TN }} & \text { nitrogen } \\ \mathbf{C O D}_{\text {Mn }} & \text { total nitrogen } \\ \mathbf{N O}_{3}^{-}-\mathbf{N} & \text { chemical oxygen demand } \\ \mathbf{N H}_{4}{ }^{+}-\mathbf{N} & \text { nitrate nitrogen }\end{array}$

\section{Acknowledgements}

This work was supported by the National Natural Science Foundation of China (41371098, 41571108, and 41323001); the Natural Science Foundation of Jiangsu Province, China (BK20151614); the Special Fund of State Key Laboratory of Hydrology-Water Resources and Hydraulic Engineering (20145027312，20155019012); Fundamental Research Funds for the Central Universities (2015B14214); and the Qing Lan Project of Jiangsu Province.

\section{References}

1. FRANCIS C.A., ROBERTS K.J., BEMAN J.M., SANTORO A.E., OAKLEY B.B. Ubiquity and diversity of ammoniaoxidizing archaea in water columns and sediments of the ocean. P Natl Acad Sci USA 102 (41), 14683, 2005.

2. HERMANSSON A., LINDGREN P.E. Quantification of ammonia-oxidizing bacteria in arable soil by real-time PCR. Appl Environ Microbiol 67 (2), 972, 2001.

3. BEMAN J.M., FRANCIS C.A. Diversity of ammoniaoxidizing archaea and bacteria in the sediments of a hypernutrified subtropical estuary: Bahia del Tobari, Mexico. Appl Environ Microbiol 72 (12), 7767, 2006.

4. JIA Z., CONRAD R. Bacteria rather than Archaea dominate microbial ammonia oxidation in an agricultural soil. Environ Microbiol 11 (7), 1658, 2009.

5. WEIDLER G.W., DORNMAYR-PFAFFENHUEMER M., GERBL F.W., HEINEN W., STAN-LOTTER H. Communities of Archaea and Bacteria in a subsurface radioactive thermal spring in the Austrian Central Alps, and evidence of ammonia-oxidizing Crenarchaeota. Appl Environ Microbiol 73 (1), 259, 2007.

6. DI H.J., CAMERON K.C., SHEN J.P., WINEFIELD C.S., O'CALLAGHAN M., BOWATTE S. Nitrification driven by bacteria and not archaea in nitrogen-rich grassland soils. Nat Geosci 2 (9), 621, 2009.

7. BERNHARD A.E., BOLLMANN A. Estuarine nitrifiers: new players, patterns and processes. Estuar Coast Shelf $S$ 88 (1), 1, 2010.

8. HU A.Y., YAO T.D., JIAO N.Z., LIU Y.Q., YANG Z., LIU X.B. Community structures of ammonia-oxidising archaea and bacteria in high-altitude lakes on the Tibetan Plateau. Freshwater Biol 55 (11), 2375, 2010.

9. LIU B., LI Y.M., ZHANG J.P., ZHOU X.H., WU C.D. Abundance and diversity of ammonia-oxidizing microorganisms in the sediments of Jinshan Lake. Curr Microbiol 69 (5), 751, 2014.

10. ZHAO D., ZENG J., WAN W., LIANG H., HUANG R., WU Q.L. Vertical distribution of ammonia-oxidizing archaea and bacteria in sediments of a Eutrophic Lake. Curr Microbiol 67 (3), 327, 2013,

11. ZENG J., ZHAO D.Y., HUANG R., WU Q.L. Abundance and community composition of ammonia-oxidizing archaea and bacteria in two different zones of Lake Taihu. Can J Microbiol 58 (8), 1018, 2012.

12. LIU Y., ZHANG J.X., ZHAO L., LI Y.Z., DAI Y., XIE S.G. Distribution of sediment ammonia-oxidizing microorganisms in plateau freshwater lakes. Appl Microb Biot 99 (10), 4435, 2015.

13. ZHAO D.Y., LUO J., ZENG J., WANG M., YAN W.M., HUANG R. Effects of submerged macrophytes on the 
abundance and community composition of ammoniaoxidizing prokaryotes in a eutrophic lake. Environ Sci Pollut Res 21 (1), 389, 2014.

14. HERRMANN M., SAUNDERS A.M., SCHRAMM A. Archaea dominate the ammonia-oxidizing community in the rhizosphere of the freshwater macrophyte Littorella uniflora. Appl Environ Microbiol 74 (10), $3279,2008$.

15. ZHENG Y., HOU L., NEWELL S., LIU M., ZHOU J., ZHAO H., YOU L., CHENG X. Community dynamics and activity of ammonia-oxidizing Prokaryotes in intertidal sediments of the Yangtze Estuary. Appl Environ Microbiol 80 (1), 408, 2014.

16. CAO H.L., HONG Y.G., LI M., GU J.D. Diversity and abundance of ammonia-oxidizing prokaryotes in sediments from the coastal Pearl River estuary to the South China Sea. Anton Leeuw Int J G 100 (4), 545, 2011.

17. WUCHTER C., ABBAS B., COOLEN M.J.L., HERFORT L., van BLEIJSWIJK J., TIMMERS P., STROUS M., TEIRA E., HERNDL G.L., MIDDELBURG J.J. Archaeal nitrification in the ocean. Proc Natl Acad Sci USA 103 (33), 12317, 2006.

18. LIU Z.H., HUANG S.B., SUN G.P., XU Z.C., XU M.Y. Diversity and abundance of ammonia-oxidizing archaea in the Dongjiang River. Microbiol Res 166 (5), 337, 2011.

19. ERGUDER T.H., BOON N., WITTEBOLLE L., MARZORATI M., VERSTRAETE W. Environmental factors shaping the ecological niches of ammonia-oxidizing archaea. FEMS Microbiol Rev 33 (5), 855, 2009.

20. SUN W., XIA C., XU M., GUO J., WANG A., SUN G. Distribution and abundance of archaeal and bacterial ammonia oxidizers in the sediments of the Dongjiang River, a drinking water supply for Hong Kong. Microbes Environ 28 (4), 457, 2013.

21. LI M., CAO H.L., HONG Y.G., GU J.D. Spatial distribution and abundances of ammonia-oxidizing archaea (AOA) and ammonia-oxidizing bacteria (AOB) in mangrove sediments. Appl Microbiol Biot 89 (4), 1243, 2011.

22. WANG X.Y., WANG C., BAO L.L., XIE S.G. Impact of carbon source amendment on ammonia-oxidizing microorganisms in reservoir riparian soil. Ann Microbiol 65 (3), 1411, 2014.

23. MOSIER A.C., FRANCIS C.A. Relative abundance and diversity of ammonia-oxidizing archaea and bacteria in the San Francisco Bay estuary. Environ Microbiol 10 (11), 3002, 2008.

24. NICOL G.W., LEININGER S., SCHLEPER C., PROSSER J.I. The influence of soil $\mathrm{pH}$ on the diversity, abundance and transcriptional activity of ammonia oxidizing archaea and bacteria. Environ Microbiol 10 (11), 2966, 2008.

25. AVRAHAMI S., CONRAD R. Patterns of community change among ammonia oxidizers in meadow soils upon long-term incubation at different temperatures. Appl Environ Microbiol 69 (10), 6152, 2003.

26. OKANO Y., HRISTOVA K.R., LEUTENEGGER C.M., JACKSON L.E., DENISON R.F., GEBREYESUS B. Application of real-time PCR to study effects of ammonium on population size of ammonia-oxidizing bacteria in soil. Appl Environ Microbiol 70 (2), 1008, 2004.

27. HE J.Z., SHEN J.P., ZHANG L.M., ZHU Y.G., ZHENG Y.M., XU M.G. Quantitative analyses of the abundance and composition of ammonia-oxidizing bacteria and ammoniaoxidizing archaea of a Chinese upland red soil under longterm fertilization practices. Environ Microbiol 9 (9), 2364, 2007.

28. HU B.L., LIU S.A., SHEN L.D., ZHENG P., XU X.Y., LOU L.P. Effect of different ammonia concentrations on comm- unity succession of ammonia-oxidizing microorganisms in a simulated paddy soil column. PLOS One 7 (8), e44122, 2012.

29. LONG X., CHEN C.R., XU Z.H., LINDER S., HE J.Z. Abundance and community structure of ammonia oxidizing bacteria and archaea in a Sweden boreal forest soil under 19-year fertilization and 12-year warming. J Soil Sediment 12 (7), 1124, 2012.

30. ZENG J., ZHAO D., YU Z., HUANG R., WU Q.L. Temperature Responses of Ammonia-Oxidizing Prokaryotes in Freshwater Sediment Microcosms. PLOS One 9 (6), e100653, 2014.

31. WANG Y.N., KE X.B., WU L.Q., LU Y.H. Community composition of ammonia-oxidizing bacteria and archaea in rice field soil as affected by nitrogen fertilization. Syst Appl Microbial 32 (1), 27, 2009.

32. TAN H.B., XU M.K., LI X.Y., ZHANG H.W., ZHANG C.G. Effects of chlorimuron-ethyl application with or without urea fertilization on soil ammonia-oxidizing bacteria and archaea. J Hazard Mater 260 368, 2013.

33. WANG J.Q., DING J.H., GUO K. Nitrogen Budgeting of Huashan Hydrological Experiment Watershed in Chuzhou. Journal of Ecology and Rural Environment 31 (5), 677, 2015.

34. ROTTHAUWE J.H., WITZEL K.P., LIESACK W. The ammonia monooxygenase structural gene amoA as a functional marker: molecular fine-scale analysis of natural ammonia-oxidizing populations. Appl Environ Microbio 63 (12), 4704, 1997.

35. THOMPSON J.D., GIBSON T.J., PLEWNIAK F., JEANMOUGIN F., HIGGINS D.G. The CLUSTAL X windows interface: flexible strategies for multiple sequence alignment aided by quality analysis tools. Nucleic Acids Res 25 (24), 4876, 1997.

36. SCHLOSS P.D., HANDELSMAN J. Introducing DOTUR, a omputer program for defining operational taxonomic unites and estimating species richness. Appl Environ Microbio 71 (3), 1501, 2005.

37. TAMURA K., DUDLEY J., NEI M., KUMAR S. MEGA4: molecular evolutionary genetics analysis (MEGA) software version 4.0. Mol Biol Evol 24 (8), 1596, 2007.

38. HERRMANN M., SAUNDERS A.M., SCHRAMM A. Effect of lake trophic status and rooted macrophytes on community composition and abundance of ammoniaoxidizing prokaryotes in freshwater sediments. Appl Environ Microbiol 75 (10), 3127, 2009.

39. WU Y.C., XIANG Y., WANG J.J., ZHONG J.C., HE J.Z., WU Q.L. Heterogeneity of archaeal and bacterial ammoniaoxidizing communities in Lake Taihu, China. Environ Microbial Rep 2 (4), 569, 2010.

40. LIMPIYAKORN T., SONTHIPHAND P., RONGSAYAMANONT C., POLPRASERT C. Abundance of amoA genes of ammonia-oxidizing archaea and bacteria in activated sludge of full-scale wastewater treatment plants. Bioresour Technol 102 (4), 3694, 2011.

41. WANG Y.F., FENG Y.Y., MA X.J., GU J.D. Seasonal dynamics of ammonia/ammonium-oxidizing prokaryotes in oxic and anoxic wetland sediments of subtropical coastal mangrove. Appl Microbiol Biotechnol 97 (17), 7919, 2013.

42. ERGUDER T.H., BOON N., WITTEBOLLE L., MARZORATI M., VERSTRAETE W. Environmental actors shaping the ecological niches of ammonia oxidizing archaea. FEMS Microbiol Rev 33 (5), 855, 2009.

43. SUI Q.W., LIU C., DONG H.M., ZHU Z.P. Effect of ammonium nitrogen concentration on the ammoniaoxidizing bacteria community in a membrane bioreactor for the treatment of anaerobically digested swine wastewater. J Biosci Bio 118 (3), 277, 2014. 